\title{
Notas Científicas \\ Criopreservação e embriogênese somática de calos de Dimocarpus longan
}

\author{
Kazumitsu Matsumoto(1), Simon Hadi Teguh Raharjo(2), Sadanand Dhekney(2), Pamela April Moon ${ }^{(2)}$ \\ e Richard Earle Litz ${ }^{(2)}$
}

\begin{abstract}
(1)Embrapa Recursos Genéticos e Biotecnologia, Caixa Postal 02372, CEP 70849-970 Brasília, DF. E-mail: kazumoto@cenargen.embrapa.br (2) University of Florida, Tropical Research and Education Center, 18905 SW 280 St, Homestead, FL 33031-3314, USA. E-mail: sraharjo@mail.ifas.ufl.edu, sadanand@mail.ifas.ufl.edu, pamoon@mail.ifas.ufl.edu, rel@mail.ifas.ufl.edu
\end{abstract}

Resumo - Os objetivos deste trabalho foram avaliar os efeitos de crioprotetores na criopreservação e da sacarose na embriogênise somática de calos de Dimocarpus longan. Após degelo os calos foram cultivados em meio de multiplicação, e a massa da matéria fresca foi determinada. Para se obter os embriões somáticos, calos e massas pro-embriônicas foram transferidos para meio de cultura contendo diferentes concentrações de sacarose. Entre os crioprotetores, a mistura de 5\% de glicerol $+5 \%$ de dimetilsulfóxido proporcionou a maior quantidade de massa fresca dos calos. O maior número de embriões foi obtido no meio de cultura com $50 \mathrm{~g} \mathrm{~L}^{-1}$ de sacarose. Os resultados mostram que calos de Dimocarpus longan podem ser criopreservados e plântulas podem ser obtidas.

Termos para indexação: Sapindaceae, glicerol, dimetilsulfóxido, micropropagação.

\section{Cryopreservation and somatic embryogenesis of Dimocarpus longan calli}

\begin{abstract}
Cryoprotectors on cryopreservation and sucrose on somatic embryogenesis of Dimocarpus longan calli were evaluated. The post-thaw calli were cultivated on multiplication medium, and the obtained fresh matter mass was measured. In order to obtain somatic embryos, calli and pro-embryonic masses were transferred into culture medium containing different concentrations of sucrose. Among the cryoprotectors, the mixture of 5\% glycerol $+5 \%$ dimethylsulfoxide provided the largest quantity of calli fresh matter. The highest number of embryos was obtained on the culture medium with $50 \mathrm{~g} \mathrm{~L}^{-1}$ sucrose. The results show that Dimocarpus longan calli can be cryopreserved and plantlets be obtained.
\end{abstract}

Index terms: Sapindaceae, glycerol, dimethylsulfoxide, micropropagation.

Longan ou longana (Dimocarpus longan Lour.) é uma fruta tropical/subtropical, originária da região asiática (Lai et al., 2000), da mesma família (Sapindaceae) da lichia (Litchi chineses Sonn.) e pouco conhecida no Brasil. A árvore é mais rústica que a lichia e mais adaptada a ambientes adversos (Nakasone \& Paull, 1998). Mesmo na região asiática, essa espécie vem sendo cultivada numa área restrita, por falta de mudas de boa qualidade (Lai et al., 2000).

A embriogênese somática a partir de calos poderia proporcionar a obtenção de mudas mediante a micropropagação. Entretanto, em virtude de cultivo sucessivo, os calos embriogênicos perdem facilmente sua capacidade embriogênica, além de ocorrerem variações somaclonais indesejadas. Para superar este problema e conservar sua integridade genética por longo período, a criopreservação é uma técnica altamente recomendável (Wang et al., 1994; Reinhoud et al., 2000). Porém, até agora, não foi encontrada nenhuma referência sobre a criopreservação de calos de longan.

Os objetivos deste trabalho foram avaliar os efeitos de crioprotetores na criopreservação e da sacarose na embriogênese somática de calos de longan.

Calos embriogênicos de longan foram induzidos de folhas imaturas, de acordo com Litz (1988), e mantidos no meio de cultura para multiplicação. O meio de cultura foi composto da metade da concentração dos sais de macronutrientes de MS (Murashige \& Skoog, 1962), concentração integral dos micronutrientes e das vitaminas de MS, $10 \mathrm{mg} \mathrm{L}^{-1}$ de ácido ascórbico, $1 \mathrm{mg} \mathrm{L}^{-1}$ de 
ácido 2,4-diclorofenoxiacético (2,4-D), $0,2 \mathrm{mg} \mathrm{L}^{-1} \mathrm{de}$ zeatina, $30 \mathrm{~g} \mathrm{~L}^{-1}$ de sacarose e $2 \mathrm{~g} \mathrm{~L}^{-1}$ de Phytagel (Sigma). O pH do meio de cultura foi ajustado a 5,8. Após quatro semanas da última subcultura, aproximadamente $100 \mathrm{mg}$ dos calos foram transferidos para tubos de criopreservação de $2 \mathrm{~mL}$. Em cada tubo adicionou-se $1 \mathrm{~mL}$ do meio de cultura líquido, sem Phytagel, suplementado com crioprotetores, esterilizado por filtração e resfriado no gelo.

Foram avaliadas quatro composições dos crioprotetores (Tabela 1). Os ensaios prévios mostraram que todos os calos morreram quando tratados com crioprotetores e mantidos por 48 horas em temperatura ambiente, e quando criopreservados sem crioprotetor. Por esse motivo, no tratamento testemunha, calos sem crioprotetores e não criopreservados foram cultivados em meio de cultura para multiplicação, e comparados em sua capacidade de multiplicação com os criopreservados.

Os tubos de criopreservação foram transferidos a um recipiente para congelamento (Mr. Frosty, Sigma), que possibilitou abaixar a temperatura gradualmente, ou seja, $-1^{\circ} \mathrm{C} \mathrm{min}^{-1}$. O recipiente foi colocado num congelador a $-80^{\circ} \mathrm{C}$ por duas horas. Em seguida, os tubos foram transferidos para um botijão que continha $\mathrm{N}$ líquido. Os tubos foram mantidos acima do nível do $\mathrm{N}$ líquido, não submersos, a $-178^{\circ} \mathrm{C}$ por 48 horas. $\mathrm{O}$ descongelamento ocorreu com a imersão dos tubos em água a $40^{\circ} \mathrm{C}$ por cinco minutos. Em seguida, os calos foram colocados sobre papel-de-filtro para eliminar os crioprotetores por escoamento e em seguida cultivados no meio de cultura semi-sólido. As culturas foram mantidas a $26 \pm 2{ }^{\circ} \mathrm{C}$ sem luz. Após dois meses de cultura, foi determinada a massa de matéria fresca dos calos em crescimento. Foram avaliados cinco tubos com calos por tratamento.

Com o objetivo de aumentar a eficiência de regeneração e germinação de embriões somáticos a partir dos calos e da massa pró-embriônica (MPE), foram avaliados os efeitos da concentração de sacarose em meio de cultura para regeneração. Após 40 dias de cultivo em multiplicação, aproximadamente $50 \mathrm{mg}$ de calos e MPE foram transferidos para placas de Petri de $6 \mathrm{~cm}$ de diâmetro, contendo $10 \mathrm{~mL}$ de meio de cultura por placa. O meio de cultura foi composto dos sais e vitaminas de MS, $5 \%$ de água-de-coco, $7 \mathrm{~g} \mathrm{~L}^{-1}$ de ágar e suplementado com 20, 30, 40 e $50 \mathrm{~g} \mathrm{~L}^{-1}$ de sacarose, considerando-se $30 \mathrm{~g} \mathrm{~L}^{-1}$ de sacarose (Wang, 2001) como o tratamento testemunha. As culturas foram mantidas a $26 \pm 2^{\circ} \mathrm{C} \mathrm{com}$ luz $\left(12 \mu \mathrm{mol} \mathrm{m} \mathrm{m}^{-2} \mathrm{~s}^{-1}\right)$, por cinco semanas. Os números de repetições por tratamento em relação aos calos embriogênicos e às massas pró-embriônicas foram de 12 e 5 , respectivamente.

O delineamento experimental foi o inteiramente casualizado. Os dados obtidos foram submetidos à análise de variância e as médias comparadas pelo teste de Duncan a 5\% de probabilidade.

Após multiplicações por 2 meses, calos criopreservados produziram $7 \%$ a $15 \%$ da matéria fresca produzida pelos calos não criopreservados (Tabela 1). Entre os crioprotetores, aquele composto de 5\% de glicerol $+5 \%$ de dimetilsulfóxido (DMSO) proporcionou a maior quantidade de matéria fresca. A solução PVS2 (Sakai et al., 1990), composta de $30 \%$ de glicerol, $15 \%$ de DMSO, $15 \%$ de EG e $137 \mathrm{~g} \mathrm{~L}^{-1}$ de sacarose foi amplamente usada em criopreservação de ápices caulinares de plantas tropicais (Takagi, 2000). Em criopreservação de células ou calos, muitos autores usaram uma concentração mais baixa de crioprotetores do que a da solução PVS2 (Wang et al., 1994; Cornejo et al., 1995; Reinhoud et al., 2000). No presente trabalho, metade da concentração da solução PVS2 já foi tóxica para os calos de longan, corroborando os resultados anteriores.

O maior número dos embriões regenerados de calos de longan foi obtido no meio de cultura com $50 \mathrm{~g} \mathrm{~L}^{-1} \mathrm{de}$ sacarose e, no caso das massas pró-embriônicas, houve boa germinação em todos os tratamentos, os quais não diferiram significativamente entre si (Tabela 2). Isto significa que, pelo menos na fase inicial da formação dos embriões, a sacarose tem um papel muito importante. Lai et al. (2000) também relataram que concentrações

Tabela 1. Massa de matéria fresca de calos embriogênicos de longan cultivados em meio de cultura para multiplicação após a criopreservação com diferentes crioprotetores ${ }^{(1)}$.

\begin{tabular}{lcr}
\hline Crioprotetor $^{(2)}$ & Matéria fresca de calos (g) & Crescimento relativo (\%) \\
\hline Testemunha & $1,406 \pm 0,207 \mathrm{a}$ & 100 \\
$5 \%$ Glicerol + 5\% DMSO & $0,204 \pm 0,066 \mathrm{~b}$ & 15 \\
$10 \%$ Glicerol + 10\% DMSO & $0,101 \pm 0,006 \mathrm{c}$ & 7 \\
$5 \%$ Glicerol + 5\% DMSO + 5\% PEG & $0,136 \pm 0,014 \mathrm{c}$ & 10 \\
$15 \%$ Glicerol + 7,5\% DMSO + 7,5\% EG & $0,142 \pm 0,014 \mathrm{c}$ & 10 \\
\hline
\end{tabular}

${ }^{(1)}$ Médias \pm erro-padrão seguidas pela mesma letra não diferem entre si pelo teste de Duncan a 5\% de probabilidade; a massa de matéria fresca inicial dos calos foi de aproximadamente $100 \mathrm{mg} .{ }^{(2)}$ DMSO: dimetilsulfóxido; PEG: polietilenoglicol; EG: etilenoglicol. 
Tabela 2. Número de embriões regenerados dos calos embriogênicos e número de embriões germinados das massas próembriônicas de longan, cultivados em meio de cultura com diferentes concentrações de sacarose ${ }^{(1)}$.

\begin{tabular}{|c|c|c|c|c|}
\hline \multirow[t]{2}{*}{ Variável } & \multicolumn{4}{|c|}{ Sacarose $\left(\mathrm{g} \mathrm{L}^{-1}\right)$} \\
\hline & 20 & 30 & 40 & 50 \\
\hline Calo embriogênico & $5,75 \pm 0,35 a$ & $6,08 \pm 0,57 a$ & $9,75 \pm 0,97 b$ & $13,33 \pm 1,09 \mathrm{c}$ \\
\hline Massa pró-embriônica & $4,0 \pm 1,00 \mathrm{a}$ & $3,2 \pm 0,58 \mathrm{a}$ & $4,3 \pm 0,47 \mathrm{a}$ & $5,8 \pm 1,53 \mathrm{a}$ \\
\hline
\end{tabular}

de 50 a $60 \mathrm{~g} \mathrm{~L}^{-1}$ de sacarose foram adequadas na maturação dos embriões somáticos de longan, apesar desses autores não terem mencionado os detalhes das condições de cultura. Os embriões germinaram e formaram plântulas normais.

Os resultados do presente trabalho mostram que calos embriogênicos de longan podem ser criopreservados e plântulas podem ser obtidas.

\section{Agradecimentos}

À Empresa Brasileira de Pesquisa Agropecuária, pela concessão de licença sabática; à Universidade da Florida, pelo suporte laboratorial e financeiro, através do projeto Agricultural Experiment Station Journal Series No. R-09785.

\section{Referências}

CORNEJO, M.-J.; WONG, V.L.; BLECHI, A.E. Cryopreserved callus: a source of protoplasts for rice transformation. Plant Cell Reports, v.14, p.210-214, 1995.

LAI, Z.X.; CHEN, C.L.; ZENG, L.H.; CHEN, Z.G. Somatic embryogenesis in longan (Dimocarpus longan Lour.). In: JAIN, S.M.; GUPTA, P.K.; NEWTON, R.J. (Ed.). Somatic embryogenesis in woody plants. Dordrecht: Kluwer Academic, 2000. v.6, p.415-431.
LITZ, R.E. Somatic embryogenesis from cultured leaf explants of the tropical tree Euphoria longan Stend. Journal of Plant Physiology, v.132, p.190-193, 1988.

MURASHIGE, T.; SKOOG, F. A revised medium for rapid growth and bioassays with tobacco tissue culture. Physiologia Plantarum, v.15, p.473-497, 1962.

NAKASONE, H.Y.; PAULL, R.E. Tropical fruits. Oxon: CAB International, 1998. 445p.

REINHOUD, P.J.; VAN IREN, F.; KIJNE, J.W. Cryopreservation of undifferentiated plant cells. In: FLORENT, E.; TAKAGI, H. (Ed.). Cryopreservation of tropical plant germplasm: Current research progress and application. Tsukuba: JIRCAS; Rome: IPGRI, 2000. p.91-102.

SAKAI, A.; KOBAYASHI, S.; OIYAMA, I. Cryopreservation of nucellar cells of navel orange (Citrus sinensis Osb. var. brasiliensis Tanaka) by vitrification. Plant Cell Reports, v.9, p.30-33, 1990.

TAKAGI, H. Recent developments in cryopreservation of shoot apices of tropical species. In: FLORENT, E.; TAKAGI, H. (Ed.). Cryopreservation of tropical plant germplasm: Current research progress and application. Tsukuba: JIRCAS; Rome: IPGRI, 2000. p.178-193.

WANG, J.F. Shoot tip culture and production of virus-free longan plantlets. Acta Horticulturae, n.558, p.155-160, 2001.

WANG, Z.Y.; LEGRIS, G.; NAGEL, J.; POTRYKUS, I.; SPANGENBERG, G. Cryopreservation of embryogenic cell suspensions in Festuca and Lolium species. Plant Science, v.103, p.93-106, 1994. 